\title{
港湾での津波による土砂移動計算の再現性評価 \\ Accuracy Evaluation of Numerical Simulations to Calculate Sediment Transport in Harbor due to Tsunami
}

\author{
近藤武司 ${ }^{1}$. 森本 徹 $^{2} \cdot$ 藤本典子 $^{3} \cdot$ 殿最浩司 $^{4} \cdot$ 志方建仁 $^{5}$ \\ Takeshi KONDOU, Tooru MORIMOTO, Noriko FUJIMOTO, Koji TONOMO and Takemi SHIKATA
}

\begin{abstract}
Harbor facilities have been estimated damage and measures due to Tsunami based on mostly water level and velocity. However, it's been reported that they're mostly suffered from sediment transport due to Tsunami by the Great East Japan Earthquake of March 11, 2011. It's necessary to estimate accurately sediment transport for damage estimate and measure examination. Also, there's no study have sufficiently evaluated the accuracy of numerical simulation for the harbor fully improved harbor facilities. This study calculated sediment transport due to Tsunami by this Earthquake for Miyako port and evaluated the accuracy by comparing the results with bathymetry before and after each Tsunami.
\end{abstract}

\section{1. はじめに}

従来，津波による港湾施設等の被害予測や対策検討は， 主に水位や流速を基に実施されてきた。しかしながら， 2011 年 3 月 11 日に発生した東北地方太平洋沖地震では, 津波による土砂移動に起因する港湾施設被害（洗掘に伴 う防波堤堤頭部や埋立地隅角部ケーソンの転倒および航 路埋没等）も多く発生したことが報告されている（例え ば, 高橋ら，2011）。 そのため, 今後港湾施設等の津波 による被害予測や対策検討を行う際には，津波による土 砂移動の予測も精度良く行う必要があると考えられる.

一方，これまでの津波による土砂移動の研究としては, 高橋ら（1999）および藤井ら（1998）の研究を挙げるこ とができる.これらの研究では, 津波による土砂移動モ デルの開発とその再現性の検討が実施されており, 再現 性の検討は1960年チリ津波来襲前後の気仙沼湾での深浅 測量結果との比較により行っている. しかしながら, 実 地形において津波による土砂移動計算の再現性が評価さ れたものはこれらの研究以外にほとんどなく, 特に防波 堤や岸壁等が高度に整備された実港湾での再現性は十分 評価されていない, そこで, 本研究では, 岩手県の宮古 港を対象として東北地方太平洋沖地震での津波による土 砂移動計算を実施し, それと津波来襲前後の深浅測量結

\section{1}

2

3

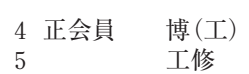

国土交通省近畿地方整備局和歌山港湾事 務所 (前国土交通省近畿地方整備局神戸 港湾空港技術調査事務所）

国土交通省近畿地方整備局神戸港湾空港 技術調查事務所

国土交通省近畿地方整備局港湾空港部港 湾空港整備・補償課(前国土交通省近畿地 方整備局神戸港湾空港技術調查事務所)

(株) ニュージェック港湾・海岸グループ

(株) ニュージェック港湾・海岸グループ
果を比較することによって再現性の評価を行った。また 併せて, 土砂移動が津波の水位に与える影響についても 検討を行った。

なお, 本研究で宮古港を対象としたのは, 東北地方太 平洋沖地震直後に深浅測量が実施されていることに加 え, 宮古港は他港に比べ防波堤が転倒するような被災が 少なかったこと（防波堤が転倒するような被災が多けれ ばその影響が土砂移動に大きく影響してくると考えられ る), および宮古港の背後地は市街化が進んでいるので 津波遡上に伴う陸域土砂の海域への流出はほとんどない と判断できることによる.

\section{2. 津波の再現計算}

津波の土砂移動計算の再現性を検討する場合, 外力と なる津波を十分再現しておく必要があると考え, まず津波 の再現計算を実施した。津波の計算は, 非線形長波方程 (浅水理論) 式を Staggered Leap-flog法により差分化して行 う一般的な方法を用いた。 また, 計算領域と計算格子は 図-1に示すように設定し, 宮古港およびその周辺での計算 格子は $10 \mathrm{~m}$ とした。 なお, 計算潮位は, 津波の最大波が宮 古港に来襲した時間の天文潮位T.P.-0.38m とした.

東北地方太平洋沖地震の断層モデルは, いくつか提案 されている.これらの断層モデルを用いて津波計算を実 施し, 宮古沖GPS 波浪計（位置は図-1 中参照）および宮 古検潮所（位置は図-1中参照）の水位の時系列変化, 宮 古港およびその周辺での浸水範囲および津波痕跡高を比 較した。その結果, 藤井・佐竹 (2011) が提案している Ver.4.6モデルのすべり量を1.1倍に補正した断層モデル が妥当な精度で最も良い一致を示したことから，これを 採用した。図-2に宮古沖GPS 波浪計で観測された津波水 位（(独）港湾空港技術研究所, 2011）と計算結果の比 


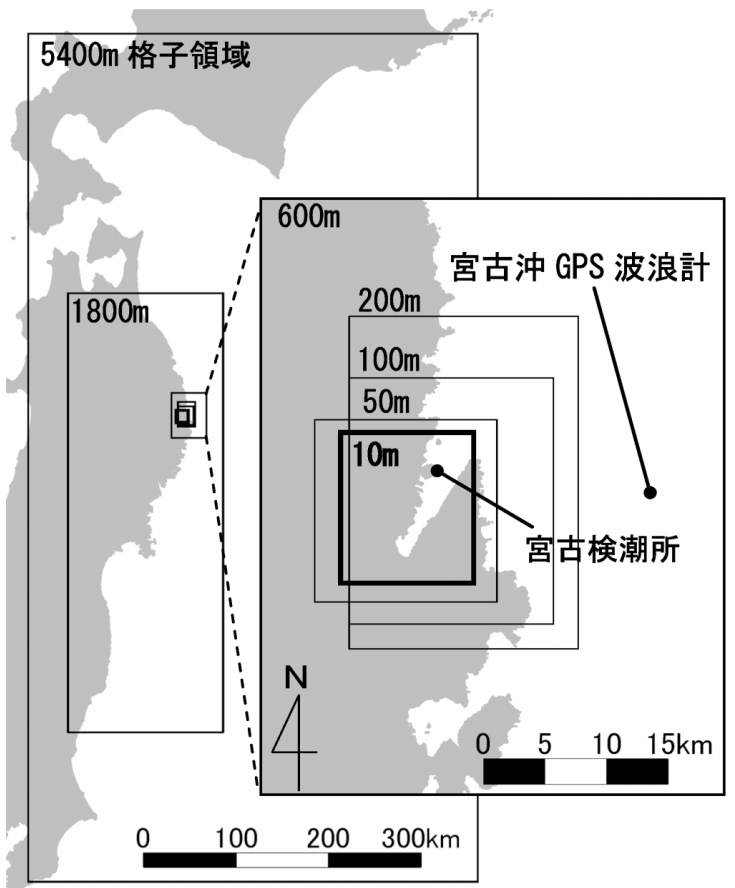

図-1 計算領域と計算格子

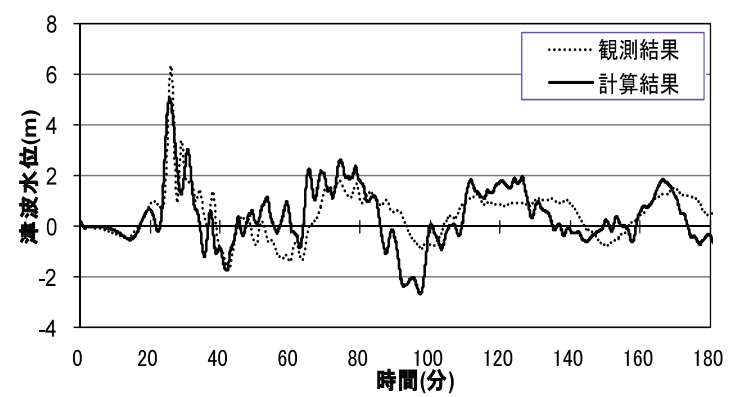

図-2 宮古沖 GPS 波浪計の津波水位と計算結果の比較

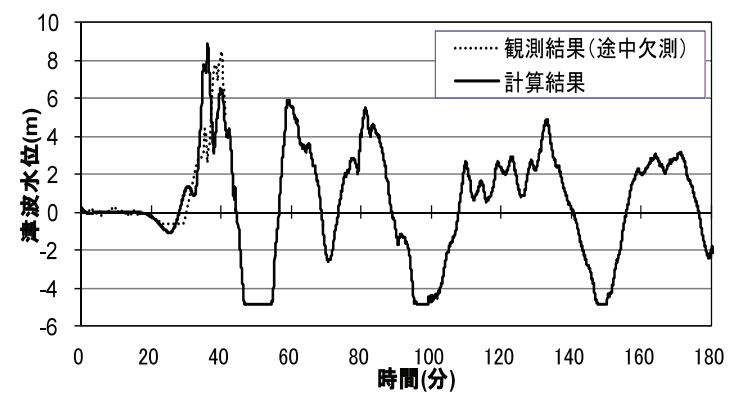

図-3 宮古検潮所の津波水位と計算結果の比較

較を，図-3に宮古検潮所で観測された津波水位（気象庁， 2011）と計算結果の比較を示す。また，図-4に宮古港お よびその周辺での浸水範囲の調査結果（国土地理院, 2011）と計算結果の比較を示す.

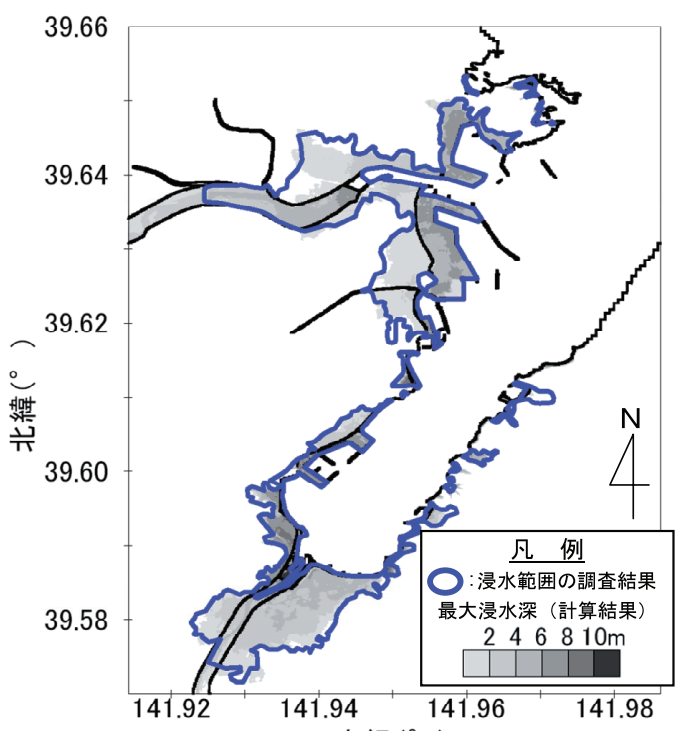

東経 $\left(^{\circ}\right)$

図-4宮古港およびその周辺での浸水範囲と計算結果の比較

\section{3. 津波による土砂移動計算および再現性評価}

\section{（1）土砂移動計算の手法および条件}

これまでに宮古港で実施された底質調査および海上ボ ーリングの資料を分析した結果，宮古港の底質は概ね細 砂（平均中央粒径 $0.08 \mathrm{~mm}$ ) に分類される。そのため, 土砂移動計算のモデルは, (社) 土木学会原子力委員会 津波研究部会（2002）のレビュー結果および著者ら （2011）の研究結果を踏まえ，掃流砂と浮遊砂を同時に 扱う高橋ら（1999）の計算モデル（以下，“高橋モデル” と記載する）を用いるものとした。なお，計算モデルの 詳細は，参考文献に示す論文を参照されたい.

土砂移動計算は，津波の計算（流体の計算）と土砂移 動の計算を連成して行うものとし，図-5に示す手順で行 った. 本計算では, 津波計算の水位・流速と土砂移動計 算の地形変化量が双方の計算にフィードバックされてい る。また，計算領域は，図-1中に示す $10 \mathrm{~m}$ 格子領域とし た.その他の土砂移動計算の条件は，表-1に示すとおり である。

(2) 計算結果

高橋モデルによる土砂移動計算の結果として, 計算領 域全体の地形変化量分布を図-6に示す。この結果，防波 堤堤頭部や狭窄部で大きく侵食（最大侵食量-11.3m） し, 港内, 防波堤背後および湾奥部で土砂が堆積（最大堆積 量 $+4.3 \mathrm{~m}$ ）している.

\section{(3) 再現性評価}

図-7は, 東北地方太平洋沖地震直後の 2011 年 3 月 30 日 〜 月 8 日に実施されたナローマルチビーム測深機によ 


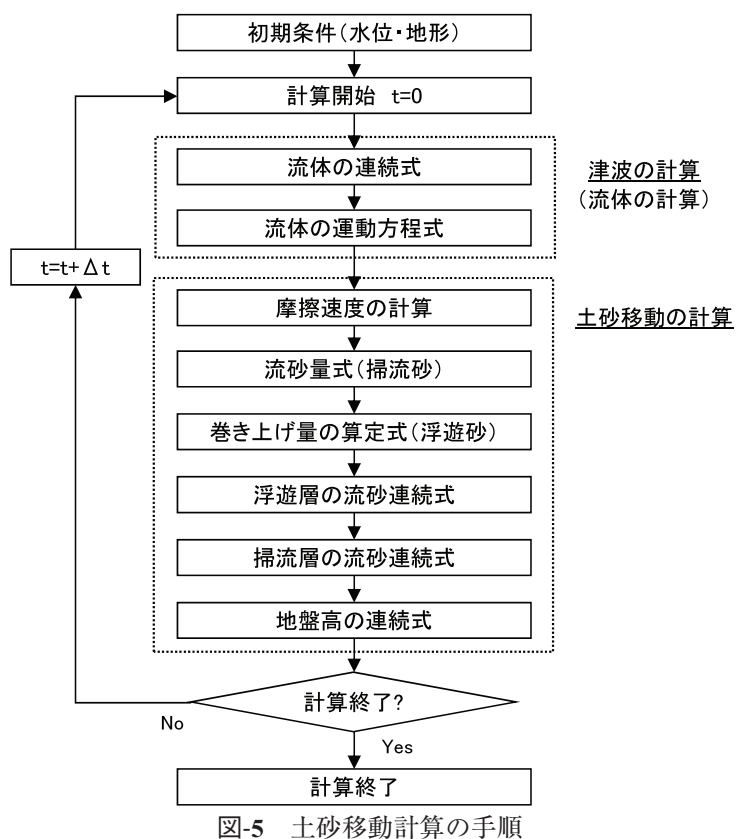

表-1 土砂移動計算の条件

\begin{tabular}{|c|c|c|c|}
\hline \multicolumn{3}{|r|}{ 設定項目 } & 設 定 值 \\
\hline \multirow{3}{*}{\multicolumn{2}{|c|}{$\begin{array}{l}\text { 底質 } \\
\text { 諸元 }\end{array}$}} & 種類 & 砂 \\
\hline & & 粒径 & $0.08 \mathrm{~mm}$ \\
\hline & & 密度 & $2.70 \mathrm{~g} / \mathrm{cm}^{3}$ \\
\hline \multirow{4}{*}{$\begin{array}{l}\text { 䚾 } \\
\text { 算 } \\
\text { 乇 } \\
\text { 兀 } \\
\text { ル }\end{array}$} & \multirow{2}{*}{ 波 } & 基礎方程式 & 非線形長波理論式および連続式 \\
\hline & & $\begin{array}{l}\text { 変数配置· } \\
\text { 計算スキーム }\end{array}$ & スタッガード・リープフロッグ法 \\
\hline & & 底質移動 & 高橋モデル \\
\hline & & 潮位条件 & T.P. $-0.38 \mathrm{~m}$ \\
\hline \multirow[b]{2}{*}{ 計 } & & $\begin{array}{c}\text { 断層（波源） } \\
\text { モデル }\end{array}$ & $\begin{array}{l}\text { 藤井・佐竹（2011）が提案している } \\
\text { Ver.4.6モデルのすべり量を1.1倍に補正 }\end{array}$ \\
\hline & 底質 & 質移動の計算領域 & 津波シミュレーションの10m格子領域 \\
\hline \multirow{2}{*}{$\begin{array}{l}\text { 算 } \\
\text { 条 }\end{array}$} & & 計算格子間隔 & $10 \mathrm{~m}$ \\
\hline & & 間格子間隔 $(\Delta \mathrm{t})$ & $0.05 \mathrm{~s}$ \\
\hline \multirow[t]{3}{*}{$\begin{array}{l}\text { 件 } \\
\text { 等 }\end{array}$} & & 海底摩擦 & $\begin{array}{l}\text { 海域：マニングの粗度係数 } \mathrm{n}=0.025 \\
\text { 陸域：土地利用状況に応じて設定 }\end{array}$ \\
\hline & & 計算時間 & 6時間 \\
\hline & & 飽和浮遊砂濃 & $1 \%$ \\
\hline
\end{tabular}

る深浅測量結果（東北地方整備局からの提供資料）と東 北地方太平洋沖地震前の深浅測量結果から地形変化量分 布を作成したものである，図-8は，図-6に示した土砂移 動計算の結果から，図-7と同じ領域を拡大して示したも のである. 図-7 と図-8を比較すると，防波堤堤頭部で大 きく侵食（洗掘）し港内や防波堤背後に土砂が堆積する 等, 土砂移動の全体的な傾向は良く一致しているものと 考えられる.

図-9は，図-7および図-8に示す断面の地形変化量を深

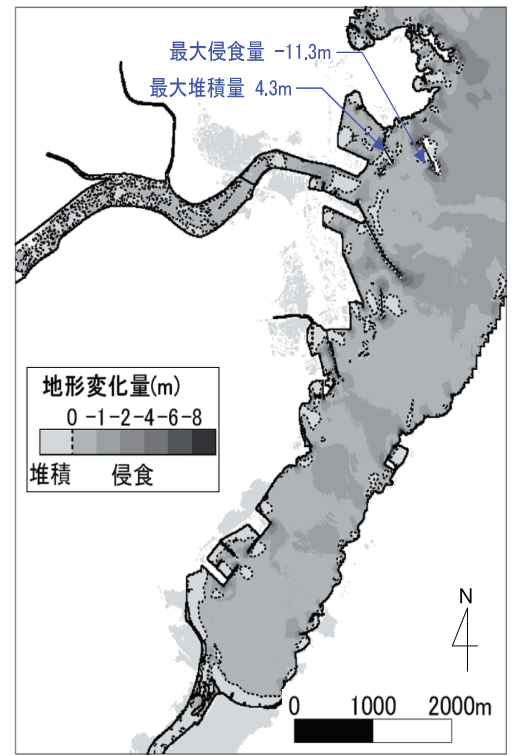

図-6 計算結果による地形変化量分布(計算領域全体)

浅測量結果と計算結果を比較して示したものである.こ の結果，両者に若干の差が見られる箇所があるが、概ね 良い一致をしているものと考えられる。特に、防波堤開 口部の断面形状および防波堤堤頭部付近の洗掘断面形状 は良い一致を示している。

表-2 は，図-7中に示した防波堤について，防波堤堤頭部 の最大洗掘深について深浅測量結果と計算結果を比較し て示したものである。この結果, 各防波堤堤頭部の最大 洗掘深の計算結果は, 深浅測量結果と概ね一致している.

また，著者ら（2011）は，過去の防波堤の被災事例を 整理し, 洗掘に伴う防波堤堤頭部の被災状況を表す指標 として, 最大洗掘深を用いて表-3に示すような3 段階の 被災ランクを設定した。表-2には, 各防波堤の被災状況 調査（東北地方整備局からの提供資料）を基にした被災 ランクと土砂移動計算による最大洗掘深から求めた被災 ランクも示した，被災状況調査による被災ランクはほほ 全てランク III となるため, 様々な被災ランクについての 比較検討はできていなが, 再者の被災ランクは藤原地区 防波堤南側堤頭部を除いて一致している.

\section{4. 土砂移動が津波の水位に与える影響検討}

ここでは，2. で示した土砂移動を考虑しない津波計 算結果（以下，“固定床の津波計算結果” 記載する) と 3. で示した土砂移動と連成させた津波計算結果（以 下, “移動床の津波計算結果” と記載する）求よび津波 痕跡高を比較することにより, 土砂移動が津波の水位に 与える影響について検討した。

図-10は, 代表地点における最大津波高を固定床と移 


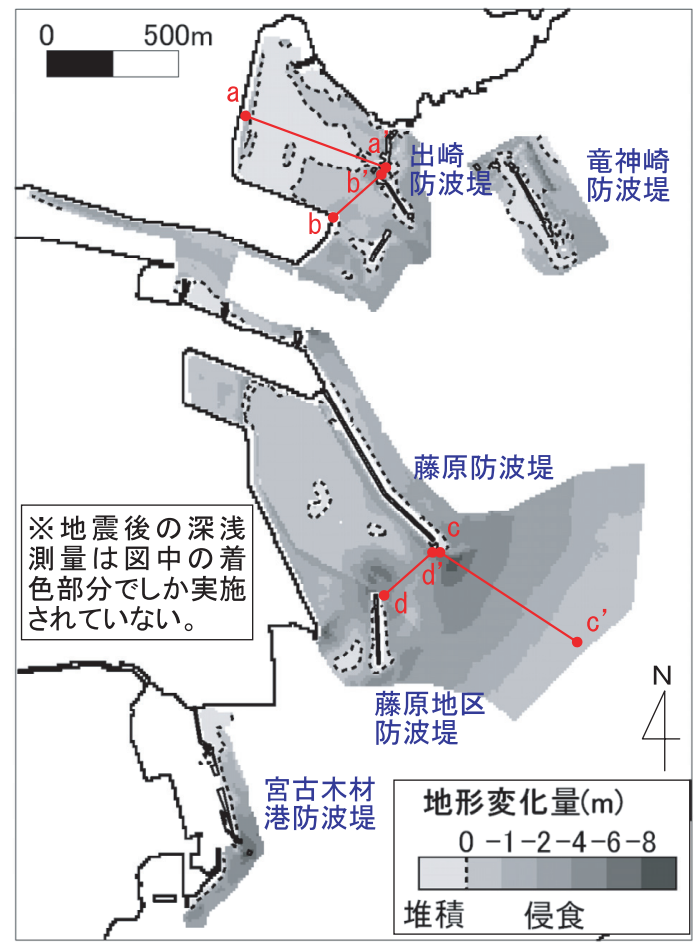

図-7 深浅測量結果による地形変化量分布

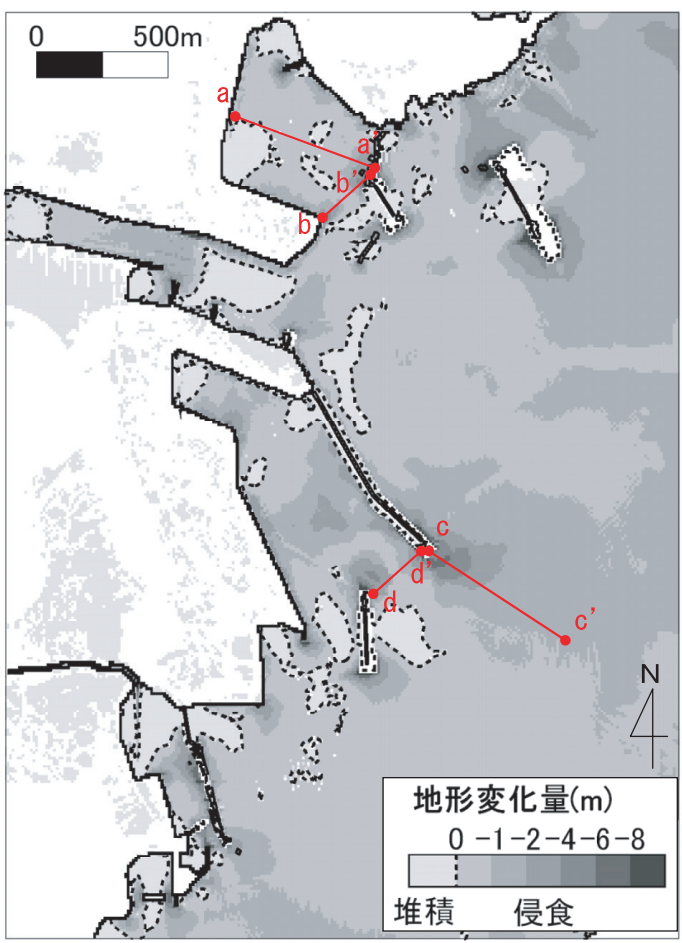

図-8 計算結果による地形変化量分布（拡大図）
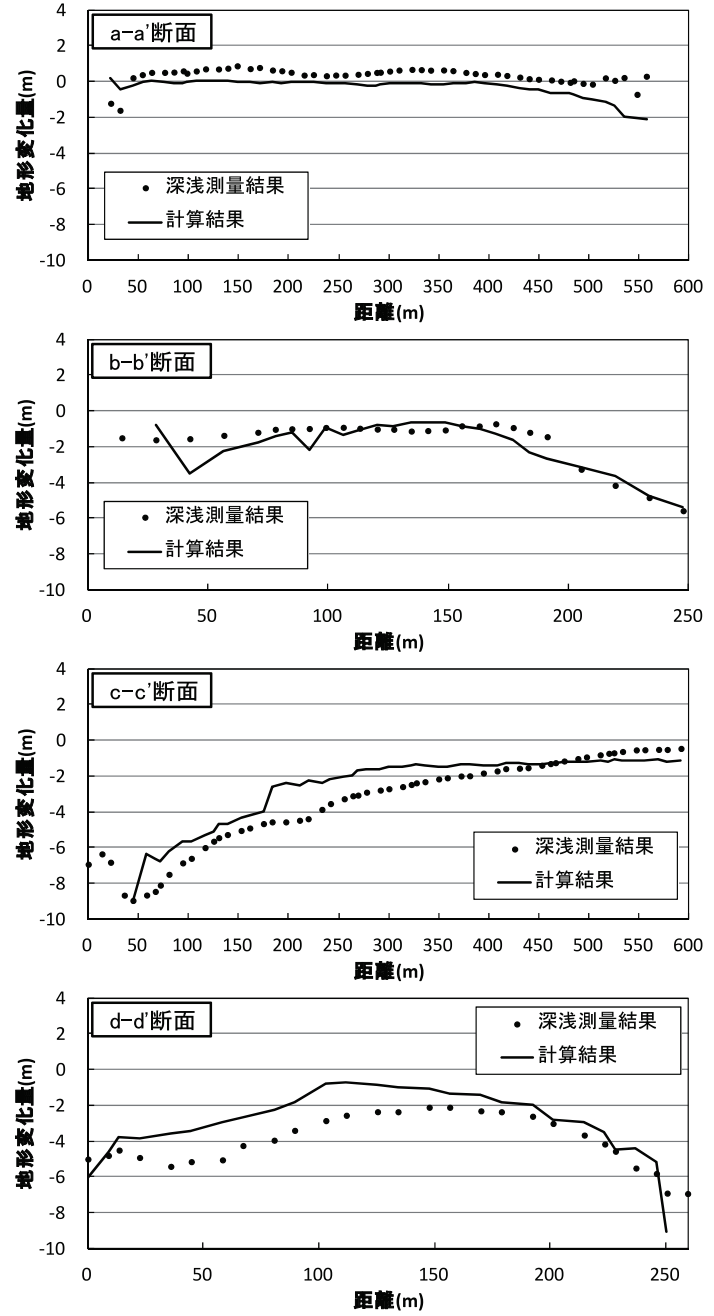

図-9 代表断面の地形変化量

表-2 防波堤堤頭部の最大洗掘深および被災ランク

\begin{tabular}{|c|c|c|c|c|c|}
\hline \multirow{2}{*}{\multicolumn{2}{|c|}{ 施設名称 }} & \multicolumn{2}{|c|}{ 洗掘深 $(\mathrm{m})$} & \multicolumn{2}{|c|}{ 被災ランク } \\
\hline & & \multirow{2}{*}{\begin{tabular}{|c|} 
深浅測量結果 \\
$\begin{array}{c}\text { 最大洗掘深 } \\
\text { が不明 }\end{array}$ \\
\end{tabular}} & \multirow{2}{*}{\begin{tabular}{|c} 
計算結果 \\
11.3
\end{tabular}} & \multirow{2}{*}{$\begin{array}{c}\text { 調査結果 } \\
\text { ランク III } \\
\text { (堤体が転倒) }\end{array}$} & \multirow{2}{*}{ 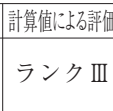 } \\
\hline \multirow{2}{*}{$\begin{array}{l}\text { 竜神崎 } \\
\text { 防波堤 }\end{array}$} & 東側堤頭部 & & & & \\
\hline & 西側堤頭部 & $\begin{array}{c}\text { 最大洗掘深 } \\
\text { が不明 }\end{array}$ & 10.5 & $\begin{array}{c}\text { ランク III } \\
\text { (堤体が転倒) }\end{array}$ & ランク III \\
\hline 出崎防波堤 & 堤頭部 & $\begin{array}{c}\text { 最大洗掘深 } \\
\text { が不明 }\end{array}$ & 8.0 & $\begin{array}{c}\text { ランク III } \\
\text { (堤体が転倒) }\end{array}$ & ランク III \\
\hline 藤原防波堤 & 堤頭部 & 9.0 & 9.1 & $\begin{array}{c}\text { ランク III } \\
\text { (堤体が輊倒) }\end{array}$ & ランク III \\
\hline \multirow{2}{*}{$\begin{array}{c}\text { 藤原地区 } \\
\text { 防波堤 }\end{array}$} & 北側堤頭部 & 6.9 & 9.1 & $\begin{array}{c}\text { ランク III } \\
\text { (堤体が転倒) }\end{array}$ & ランク III \\
\hline & 南側堤頭部 & 6.3 & 8.1 & $\begin{array}{l}\text { ランク II } \\
\text { (マウンドが崩壊) }\end{array}$ & ランク III \\
\hline $\begin{array}{c}\text { 宮古木材港 } \\
\text { 防波堤 }\end{array}$ & 堤頭部 & 8.6 & 8.0 & \begin{tabular}{|l} 
ランク III \\
(堤体が転倒)
\end{tabular} & ランク III \\
\hline
\end{tabular}


表-3 防波堤堤頭部の被災ランクの設定

\begin{tabular}{|c|c|c|c|}
\hline 被㷋ランク & 状態 & 概念図 & 洗掘深 $\triangle \mathrm{h}$ \\
\hline ランク I & $\begin{array}{l}\text { マウンドのり先お } \\
\text { よびマウンド斜 } \\
\text { 面部が沈下した } \\
\text { 状態 }\end{array}$ & 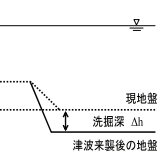 & $1.5 \mathrm{~m} \leqq \Delta \mathrm{h}<3.0 \mathrm{~m}$ \\
\hline ランク II & $\begin{array}{l}\text { マウンドの水平部 } \\
\text { 分も含め沈下ま } \\
\text { たは崩壊した状 } \\
\text { 態(ただ、堤体 ( } \\
\text { ケーソン等)の傾 } \\
\text { 斜等はない状態) }\end{array}$ & 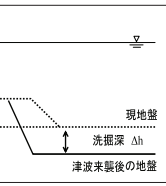 & $3.0 \mathrm{~m} \leqq \Delta \mathrm{h}<4.0 \mathrm{~m}$ \\
\hline ランク III & $\begin{array}{l}\text { マウンド全体が } \\
\text { 崩壊し、堤体 (ケ } \\
\text { ーソン等) が傾 } \\
\text { 斜もしくは転倒し } \\
\text { た状態 }\end{array}$ & 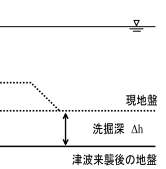 & $4.0 \mathrm{~m} \leqq \Delta \mathrm{h}$ \\
\hline
\end{tabular}

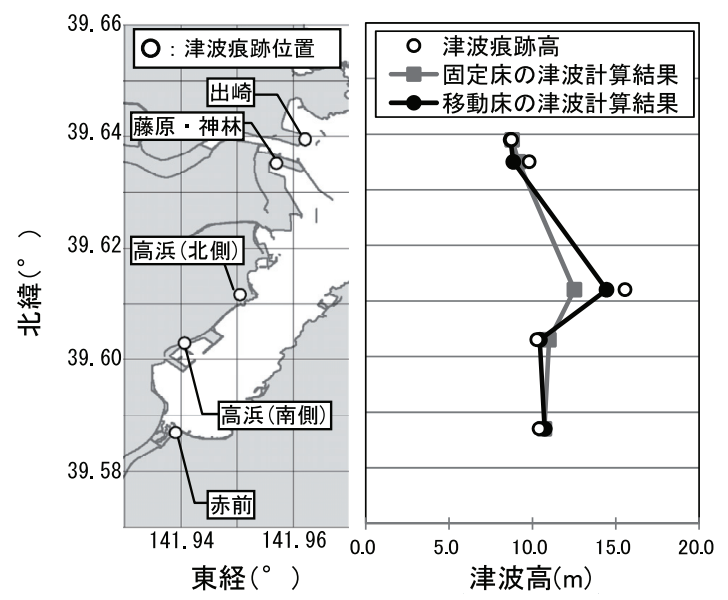

図-10 代表地点における最大津波高の比較

動床の津波計算結果および津波痕跡高（高橋ら，2011） を比較したものである. その結果, 移動床と固定床の最 大津波高には若干差が現れ，移動床のほうが固定床より も津波痕跡高により一致する傾向にある. 特に, 高浜 (北側) 地点では, 移動床の最大津波高が固定床よりも $2 \mathrm{~m}$ 程度大きい結果となる. 当該地点の前面は砂浜であり, 土砂移動の計算では，この砂浜の汀線付近が延長約 $250 \mathrm{~m}$ にわたって約 $3 \mathrm{~m}$ 侵食される結果となっている. そのた め, 陸上部の津波流入量が固定床に比べて増大し, 移動 床の津波高が大きくなったものと考えられる.

\section{5. おわりに}

本研究では, 宮古港を対象として東北地方太平洋沖地 震での津波による土砂移動計算を高橋モデルで実施し, それと津波来襲前後の深浅測量結果を比較することによ って再現性の評価を行った. 主要な結論をまとめると以 下のとおりである。
（1）高橋モデルによる土砂計算結果と深浅測量結果によ る地形変化を比較した結果, 防波堤堤頭部で大きく侵 食（洗掘）し港内や防波堤背後に土砂が堆積する等, 土砂移動の全体的な傾向は良く一致する.

（2）全体的な傾向だけでなく，防波堤堤頭部の最大洗掘 深や断面地形も定量的に概ね良い一致を示す.

（3）これらのことから, 高橋モデルは実港湾での津波に よる土砂移動を十分な精度で再現でき, 土砂移動に起 因する港湾施設等の被害予測および対策検討に用いる ことが可能である.

（4）移動床と固定床の津波計算結果を比較すると，移動 床のほうが津波痕跡高により一致する傾向にある.

今後は, 本研究結果を踏まえて防災計画や事業継続計 画（BCP）の立案時には, 津波による土砂移動の被害想 定や対策を含めて検討を実施したいと考えている.

最後に, 本研究を実施するにあたり, 国土交通省東北 地方整備局仙台港湾空港技術調査事務所より深浅測量結 果および防波堤の被災状況調査結果を，（独）港湾空港 技術研究所より津波計算の計算データを提供いただい た.また, 関西大学社会安全学部の高橋智幸教授および 仙台港湾空港技術調査事務所の寺崎賢次先任建設管理 官，佐藤隆二建設管理官から貴重な助言をいただいた. ここに記して感謝の意を表します。

\section{参 考 文 献}

気象庁 (2011) : 「宮古」, 「大船渡」の津波観測点の観測値に ついて, 気象庁報道発表資料, 平成 23 年 3 月 23 日 14 時 00 分, http://www.jma.go.jp/jma/press/1103/23b/stn03231400.pdf, 参 照2011-11-29.

（独）港湾空港技術研究所（2011）：東北地方太平洋沖地震に よる津波観測データ, http://nowphas.mlit.go.jp/ nowphasdata/sub301.htm, 参照2011-12-28.

国土地理院（2011）：平成 23 年（2011年）東日本大震災 2.5 万 分 1 浸水範囲概況図 (岩手県版), 国土地理院技術資料 D · 1-No.593, http://www.gsi.go.jp/kikaku/kikaku40016.html, 参照2012-01-08.

近藤武司 - 森本 徹 - 藤本典子 - 殿最浩司 - 家村健吾 - 志方 建仁（2011）：津波による土砂移動が港湾施設に与える影 響に関する研究,土木学会論文集 B2 (海岸工学), Vol.67, pp.261-265.

(社) 土木学会原子力土木委員会津波評価部会（2002）：原子 力発電所の津波評価技術, pp.3-32-3-33.

高橋重雄他（2011）：2011年東日本大震災による港湾・海岸・ 空港の地震 ・津波被害に関する調査速報, 港湾空港技術 研究所資料, No.1231, pp.1-175.

高橋智幸・首藤伸夫 - 今村文彦・浅井大輔（1999）：掃流層・ 浮遊層間の交換砂量を考慮した津波移動床モデルの開発, 海岸工学論文集, 第46巻, pp.606-610.

藤井雄士郎・佐竹健治（2011）：2011年3月 11 日東北地方太平 洋沖地震の津波波源, http://iisee.kenken.go.jp/staff/fujii/ OffTohokuPacific2011/tsunami_ja.html, 参照2011-12-01.

藤井直樹 - 大森政則 - 高尾誠 - 金山進 - 大谷英夫 （1998）：津波による海底地形変化に関する研究, 海岸工 学論文集, 第 45 巻, pp.376-380. 